\title{
PELATIHAN PENGEMBANGAN INSTRUMEN PENILAIAN PENDIDIKAN KARAKTER PADA KURIKULUM 2013
}

\author{
Feniareny. DA ${ }^{1}$, Miftha Indasari ${ }^{2}$, Imelda Ratih Ayu $^{3}$, \\ Adrianus Dedi ${ }^{4}$, Pranita Yuliana 5 \\ Program Studi Pendidikan Guru Sekolah Dasar Universitas PGRI Palembang \\ E-mail: feniareny@gmail.com ${ }^{1}$, mifthaindasari21@gmail.com ${ }^{2}$, \\ imelda_ratihayu@yahoo.com ${ }^{3}$, adrianusdedy@yahoo.co.id ${ }^{4}$, yulianapranita89@gmail.com ${ }^{5}$
}

\begin{abstract}
Abstrak
Kegiatan pengabdian kepada masyarakat ini bertujuan untuk memberikan kepada guru-guru Sekolah Dasar tentang pengembangan instrumen penilaian pendidikan karakter pada kurikulum 2013 sehingga guru-guru dapat menerapkannya di kelas masing-masing. Metode yang diterapkan dalam pengabdian ini adalah metode ceramah digunakan untuk memberikan penjelasan tentang materi yang akan disampaikan, metode tanya jawab digunakan untuk menggali pemahaman guru terhadap materi yang akan diberikan dan Workshop digunakan untuk melatih dan membimbing guru dalam pengembangan instrumen penilain pendidikan karakter. Hasil menunjukkan bahwa pelatihan pengembangan instumen penilaian pendidikan karakter pada kurikulum 2013 dikatakan efektif untuk memudahkan guru-guru Sekolah Dasar dalam melaksanakan penilaian dalam pembelajaran dalam rangka pendidikan karakter dan pada gilirannya implementasi pendidikan karakter bagi peserta didik Sekolah Dasar dapat berlangsung guna mendukung terwujudnya tujuan pendidikan nasional.
\end{abstract}

Kata kunci : Instrumen Penilaian, Penndidikan Karakter, Kurikulum 2013

\begin{abstract}
This community-dedicated service aims to provide elementary school teachers with the development of a character education assessment instrument in the 2013 curriculum so that teachers can apply it in their own classes. The method applied in this devotion is Lecture method is used to give explanation about the material that will be submitted. Question and answer method is used to explore the teacher's understanding on the material that will be given and the workshop is used to train and guide the teacher in the development of character education appraisal instruments. The results show that the training of character development of character education assessment in the 2013 curriculum is said to be effective to facilitate elementary school teachers in carrying out the assessment in learning in the context of character education and in turn the implementation of character education for elementary school students can take place to support the realization of national education goals.
\end{abstract}

Keywords: Assessment Instrument, Character Education, Curriculum 2013 


\section{Pendahuluan}

Fungsi dan tujuan pendidikan nasional, menunjukkan bahwa pendidikan di setiap jenjang, termasuk Sekolah Dasar (SD) harus diselenggarakan secara sistematis guna mencapai tujuan tersebut. Hal tersebut berkaitan dengan pembentukan karakter peserta didik sehingga mampu bersaing, beretika, bermoral, sopan santun dan berinteraksi dengan masyarakat.

Permasalahan besar yang dihadapi bangsa Indonesia saat ini adanya indikasi penurunan nilai karakter yang dimiliki oleh warga negara Indonesia. Sudah lebih dari enam dasawarsa, pelaksanaan pembelajaran pada mata pelajaran Sosial Humaniora, seperti: Pendidikan Agama, PKn, IPS, \& Pancasila yang dilakukan sejak SD hingga perguruan tinggi belum menampak pada kualitas lulusannya.

Pendidikan karakter memang sudah digulirkan dan bahkan sudah disosialisasikan ke sekolah-sekolah. Namun demikian implementasi pendidikan karakter pada peserta didik masih memerlukan seperangkat pembelajaran pendukung dan memadai yang meliputi silabus, rencana pembelajaran, pelaksanaan pembelajaran yang inovatif, media pembelajaran, dan instrumen penilaian.

Selama ini, guru baru mengembangkan unsur-unsur pembelajaran secara umum, sedangkan sistem penilaian masih sebatas kawasan kognitif. Hal ini disebabkan oleh praktik pendidikan di Indonesia yang cenderung lebih berorentasi pada pendidikan berbasis hard skill (keterampilan teknis) yang lebih bersifat mengembangkan intelligence quotient (IQ), dan kurang mengembangkan kemampuan soft skill yang tertuang dalam emotional quotient (EQ), dan spiritual quotient (SQ).

Unsur-unsur yang telah dirumuskan oleh Kementerian Pendidikan dan Kebudayaan dalam implementasi pendidikan karakter masih berkisar pada (1) deskripsi, (2) indikator sekolah, dan (3) indikator kelas secara umum. Dimana pelaksanaan kegiatan pembelajaran tersebut belum mengarah untuk mengembangkan pencapaian nilai-nilai karakter, melainkan masih bersifat sebagai tujuan pengiring. Selain itu, evaluasi secara khusus pencapaian nilai-nilai karakter juga belum dilaksanakan.

Dalam hal penilaian pendidikan karakter, belum tersedia instrumen dari berbagai model yang dapat digunakan secara tepat. Guru masih kesulitan untuk menyusun instrumen penilaian pendidikan karakter. Untuk itu perlu mengetahui instrumen penilaian pendidikan karakter dalam pembelajaran di Sekolah Dasar sesuai dengan karakteristik anak usia SD. Dengan mengetahui instrumen penilaian pendidikan karakter dalam pembelajaran di SD akan dapat memudahkan guru-guru SD dalam melaksanakan penilaian dalam pembelajaran dalam rangka pendidikan karakter dan pada gilirannya implementasi pendidikan karakter bagi peserta didik SD dapat berlangsung guna mendukung terwujudnya tujuan pendidikan nasional.

Menurut Pusat Bahasa Depdiknas, karakter adalah "bawaan, hati, jiwa, kepribadian, budi pekerti, perilaku, personalitas, sifat, tabiat, temperamen, watak". Sehingga, orang yang berkarakter adalah orang yang berkepribadian, berperilaku, bersifat, bertabiat, berwatak". Samami (2011:43) mengemukakan bahwa 
karakter dimaknai sebagai nilai dasar yang membangun pribadi seseorang, terbentuk baik karena pengaruh hereditas maupun lingkungan, yang membedakan dengan orang lain, serta diwujudkan dalam sikap dan perilaku dalam kehidupan sehari-hari (Hidayatullah, 2009:9).

Pendidikan karakter dapat diintegrasikan dalam pembelajaran pada setiap mata pelajaran. Materi pembelajaran yang berkaitan dengan norma atau nilai-nilai pada setiap mata pelajaran perlu dikembangkan, dieksplisitkan, dikaitkan dengan konteks kehidupan sehari-hari. Dengan demikian, pembelajaran nilai-nilai karakter tidak hanya pada tataran kognitif, tetapi menyentuh pada internalisasi, dan pengamalan nyata dalam kehidupan peserta didik sehari-hari di masyarakat.

Penilaian adalah suatu proses untuk mengetahui keberhasilan suatu program kegiatan yang sesuai dengan tujuan atau kriteria yang telah ditetapkan. Penilaian dapat dilakukan dengan tepat apabila tersedia data yang sesuai dan memadai. Guna memperoleh data diperlukan instrumen penilaian dari berbagai model yang sesuai dengan tujuan. Untuk mengetahui keberhasilan dalam pembelajaran penanaman nilai-nilai karakter diperlukan instrumen penilaian yang sesuai dengan tujuannya, dengan cara membandingkan perilaku anak dengan standar (indikator) karakter yang ditetapkan. Menurut Kesuma, Triatna, \& Permana, (2011:138) tujuan evaluasi pendidikan karakter adalah: (1) mengetahui kemajuan hasil belajar dalam bentuk kepemilikan sejumlah indikator karakter tertentu pada anak dalam kurun waktu tertentu, (2) mengetahui kekurangan dan kelebihan desain pembelajaran yang dibuat guru, (3) mengetahui tingkat efektivitas proses pembelajaran yang dialami oleh anak, baik pada setting kelas, sekolah, maupun rumah.

\section{Bahan dan Metode Pelaksanaan}

Kegiatan pelatihan pengembangan penilaian pendidikan karakter pada kurikulum 2013 dilaksanakan selama satu hari yaitu Senin, 7 Mei 2018 bertempat di SD Negeri 89 Palembang. Khalayak sasaran pada kegiatan pengabdian pada masyarakat ini yaitu guru-guru di Sekolah Dasar Negeri 89 Palembang semester genap tahun ajaran 2017/2018 sebanyak 25 orang dengan durasi 5 jam.

Panitia penyelenggara adalah LPPkMK Universitas PGRI Palembang. Mekanisme kegiatan ini dilaksanakan berdasarkan rancangan umum kegiatan pelatihan yang dikoordinasi oleh LPPkMK Universitas PGRI Palembang. Penyampaian materi kegiatan ini dilaksanakan dengan tiga metode sebagai berikut:

a. Metode ceramah digunakan untuk memberikan penjelasan tentang materi yang akan disampaikan.

b. Metode tanya jawab digunakan untuk menggali pemahaman guru terhadap materi yang akan diberikan.

c. Workshop digunakan untuk melatih dan membimbing guru dalam pengembangan instrumen penilain pendidikan karakter.

\section{Hasil dan Pembahasan}

Kegiatan pengabdian kepada masyarakat dosen Program Studi Pendidikan Guru Sekolah Dasar ini telah dilaksanakan pada hari Senin, 7 Mei 2018 dari pukul 08.00 - 13.00 WIB, bertempat di Ruang 
Kelas SD Negeri 89 Palembang Jl. A. Yani Lrg. Manggis No.13 Kec. Jakabaring Palembang. Kegiatan pengabdian pada masyarakat ini telah diikuti oleh guru -guru SD Negeri 89 Palembang dengan jumlah peserta sebanyak 25 orang. Dapat dilihat dari beberapa dokumentasi pelatihan yang dirangkum berikut ini.

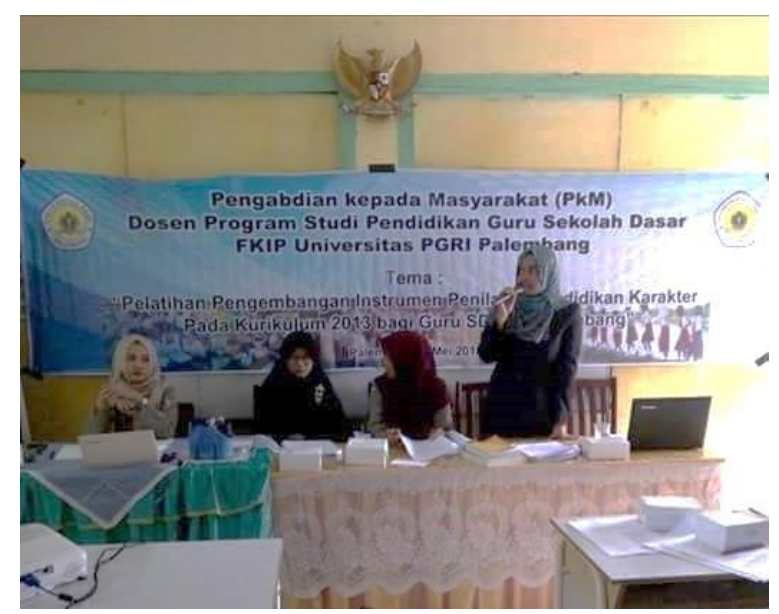

Gambar 1. Pemaparan Materi oleh Dosen PGSD Universitas PGRI Palembang

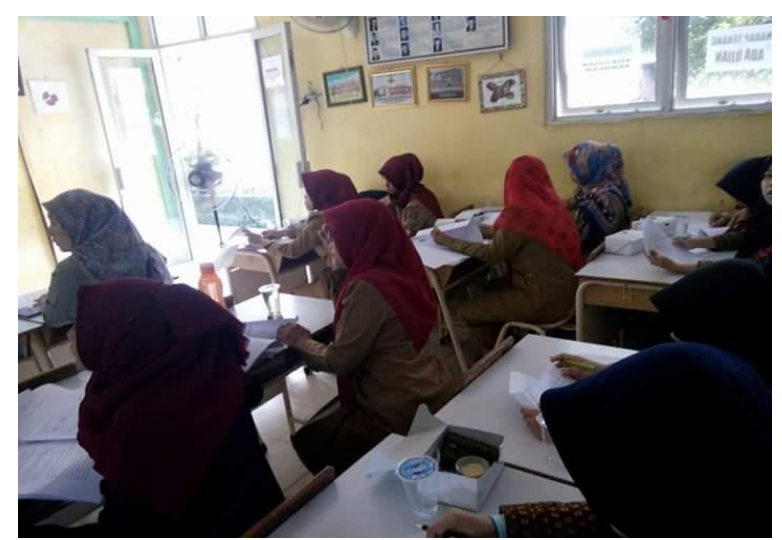

Gambar 2. Peserta Mendengarkan Penyampaian Materi Pelatihan

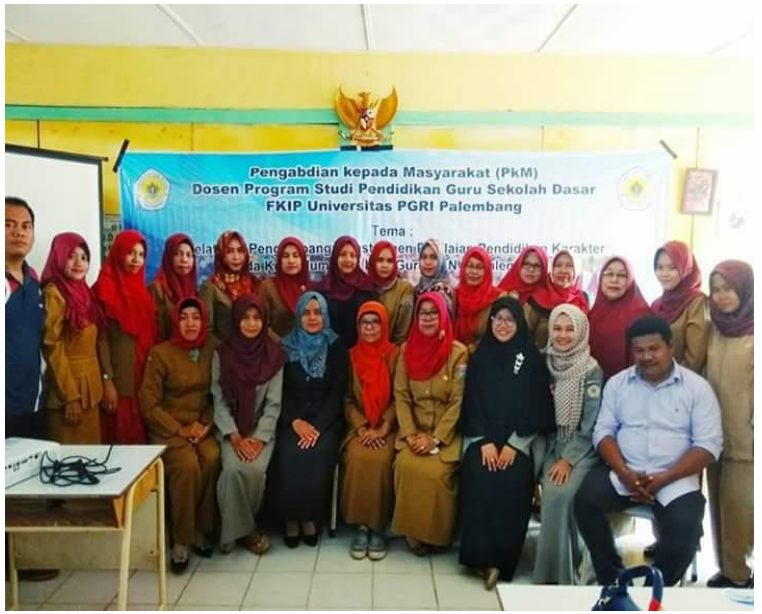

Gambar 3. Peserta Pelatihan Pengembangan Instrumen Penilaian Pendidikan Karakter

Pemaparan materi yang diarahkan oleh moderator dengan menggunakan metode ceramah. Penyampaian materi dilakukan secara panel oleh masing-masing dosen disesuaikan dengan jenis materi, kondisi dan waktu.

Penilaian pendidikan karakter dapat dilakukan dengan berbagai model seperti observasi, anecdotal record, wawancara, portofolio, skala bertingkat, dan evaluasi diri (Mulyasa. 2016).

\section{a. Anecdotal Record}

Anecdotal record adalah kumpulan rekaman/catatan tentang peristiwa-peristiwa penting yang menonjol dan menarik perhatian berkaitan dengan karakter peserta didik dalam situasi tertentu.

\section{b. Observasi}

Observasi adalah pengumpulan data yang pengisiannya berdasarkan pada pengamatan langsung terhadap sikap dan perilaku peserta didik dengan cara pembiasaan, keteladanan, dan pembentukan karakter peserta didik. Contoh instrumen penialian observasi. 


\section{c. Wawancara}

Wawancana adalah percakapan antara dua orang atau lebih dan berlangsung antara narasumber dan pewawancara. Tujuan dari wawancara adalah untuk mendapatkan informasi yang tepat dari narasumber yang terpercaya. Wawancara dilakukan dengan cara penyampaian sejumlah pertanyaan dari pewawancara kepada narasumber.

\section{d. Skala Bertingkat}

Skala penilaian memuat daftar kata-kata atau persyaratan mengenai perilaku, sikap, dan atau kemampuan peserta didik. Skala penilaian dapat berbentuk bilangan, huruf, dan ada pula yang berbentuk uraian.

Skala penilaian yang berbentuk bilangan terdiri dari pernyataan atau kata atau lainnya, dan disebelahnya disediakan bilangan tertentu, misalnya 1 sampai 5 . Pengamat tinggal memberi tanda checklist ( $\sqrt{ }$ ) pada kolom salah satu perilaku yang muncul dan lanjur skala atau angka yang diamati.

\section{e. Evaluasi Diri}

Evaluasi diri adalah penilaian yang dilakukan dengan menetapkan kemampuan yang telah dimiliki seseorang dari suatu kegiatan pembelajaraan atau kegiataan lainnya dalam rentangan waktu tertentu. Dapat diartikan, penilaian tersebut dapat dilakukan seseorang untuk menilai dirinya sendiri. Evaluasi diri dapat dilakukan umtuk pendidikan karakter. Karena adanya kritikan bahwa cara penilaian yng dilakukan belum menyeluruh.

Evaluasi diri sendiri pada pendidikan karakter dilakukan peserta didik dengan bantuan guru. Peserta didik dibantu untuk menganalisis hasil kerja atau merasakan apa yang telah dilakukannya dengan bantuan guru, yaitu bisa dengan mengisi daftar isian dengan memberikan tanda check list terhadap hasil kerja dan proses pembelajaraan yang telah dilaluinya. Format check list bisa dalam bentuk gambar yang menunjukan ekspresi, atau setelah anak memiliki hasil kumpulan kerjanya.

\section{f. Portofolio}

Portofolio adalah kumpulan tugas-tugas yang dikerjakan peserta didik. Portofolio digunakan untuk mengukur prestasi belajar peserta didik yang bertumpu pada perbedaan individual. Selanjutnya dibuka sesi tanya jawab untuk para peserta pelatihan yang akan dijawab oleh pemateri. Para peserta pelatihan sangat antusias mengikuti kegiatan ini, banyak guru-guru yang ingin bertanya dan menjawab ketika diberikan pertanyaan oleh pemateri. Terakhir pelatihan mengembangkan instrumen penilaian pendidikan karakter pada kurikulum 2013.

Berapa contoh hasil peengembangan instrumen penilaian guru-guru SD Negeri 89 Palembang sebagai berikut:

\section{1). Instrumen Observasi}

\section{Lembar Instrumen Observasi} "Kompetensi Sikap Sosial"

\section{Nama Siswa}

Kelas/Semester $\quad:$ IV/1

Tema/Subtema

Indahnya Kebersamaan / Bersyukur atas

Keberagaman

Mata Pelajaran

Ilmu Pengetahuan Sosial ( IPS)

Kompetensi Dasar :

2.1 Menunjukkan prilaku jujur, disiplin, bertanggung jawab, peduli, santun, dan percaya diri sebagimana ditunjukkan 
oleh tokoh-tokoh pada masa HinduBudha dan Islam dalam kehidupan sekarang

Indikator

2.1.1 siswa dapat hadir disiplin mengikuti pelajaran IPS

2.1.2 siswa dapat aktif dalam menyelesaikan

\begin{tabular}{|c|c|c|c|c|c|}
\hline \multirow{2}{*}{ No } & \multirow{2}{*}{ Aspek yang diamati } & \multicolumn{3}{|c|}{ Kategori } & \multirow{2}{*}{ Ket. } \\
\hline & & $B$ & $\mathrm{C}$ & $\mathrm{K}$ & \\
\hline 5 & $\begin{array}{l}\text { Tanggung jawab sesuai } \\
\text { tugasnya dalam } \\
\text { kelompok diskusi }\end{array}$ & & & & \\
\hline 6 & $\begin{array}{l}\text { Kerja sama dalam } \\
\text { menyelesaikan tugas }\end{array}$ & & & & \\
\hline 7 & $\begin{array}{l}\text { Keseriusan menyimak } \\
\text { penjelasan guru }\end{array}$ & & & & \\
\hline 8 & $\begin{array}{l}\text { Antusiasme dalam } \\
\text { mengikuti pembelajaran }\end{array}$ & & & & \\
\hline
\end{tabular}

tugas diskusi dalam kelompok

2.1.3 Siswa dapat menunjukkan sifat santun ketika menyampaikan pendapat dalam forum

2.1.4 Siswa dapat menghargai perbedaan pendapat di dalam forum

2.1.5 Siswa dapat bertanggung jawab dalam mengerjakan tugas kelompok diskusi kelas

2.1.6 Siswa dapat menunjukkan sikap antusias saat mengikuti proses pembelajaran

Hari/Tanggal $\quad$ : ...............20....

Tema Penilaian Diri :

Prilaku jujur, disiplin, bertanggung jawab, peduli, sanun, dan percaya diri sebagaimana ditunjukkan oleh tokoh-tokoh pada masa hindu-Budha dan Islam

Berilah tanda centang $(\sqrt{ })$ pada kolom sesuai kriteria yang ditunjukkan siswa

Baik

: Jika aspek keriteria yang diamati muncul dengan nyata dan sesuai indikator aspek yang diamati (skor 3)

Cukup : Jika aspek keriteria yang diamati muncul dengan cukup nyata dan cukup sesuai indikator aspek yang diamati (skor 2)

Kurang : Jika aspek keriteria yang

\begin{tabular}{|c|c|c|c|c|c|}
\hline $\mathrm{N}$ & \multirow{2}{*}{ Aspek yang diamati } & \multicolumn{3}{|c|}{ Kategori } & \multirow{2}{*}{ Ket. } \\
\hline NO & & B & C & $\mathrm{K}$ & \\
\hline 1 & $\begin{array}{l}\text { Tingkat kedisiplinan } \\
\text { kehadiran }\end{array}$ & & & & \\
\hline 2 & $\begin{array}{l}\text { Keaktifan dalam } \\
\text { menyelesaikan tugas } \\
\text { dalam diskusi }\end{array}$ & & & & \\
\hline 3 & $\begin{array}{l}\text { Menyampaikan } \\
\text { pendapat dalam forum } \\
\text { secara santun }\end{array}$ & & & & \\
\hline 4 & $\begin{array}{l}\text { Menghargai pendapat } \\
\text { orang lain dalam } \\
\text { diskusi di kelas }\end{array}$ & & & & \\
\hline
\end{tabular}

Rumus Penilaian:

$$
\text { Nilai }=\frac{\text { Skor Perolehan }}{\text { SkorMaksimal }} \times 100 \%
$$

Keterangan :

Nilai 91 - 100 berarti sangat baik (sudah membudaya).

Nilai $71-90$ berarti baik (mulai berkembang)

Nilai 61 - 70 berarti cukup (mulai terlihat)

Nilai kurang dari 60 berarti kurang (belum terlihat)

(Modifikasi Prastowo, 2013)

\section{2). Instrumen Skala Bertingkat}

Lembar Instrumen Skala Bertingkat

Nama Siswa $\quad$ :........

Kelas/Semester $\quad:$ IV/1

Tema/Subtema : 
Indahnya Kebersamaan / Bersyukur atas

\section{Keberagaman}

Mata Pelajaran

Ilmu Pengetahuan Sosial ( IPS)

Kompetensi Dasar :

1.2 Menjalankan ajaran agama dalam berpikir dan berprilaku sebagai penduduk Indonesia dengan mempertimbangkan kelembagaan sosial, budaya, ekonomi dan politik dalam masyarakat

\section{Indikator}

1.2.1 Siswa dapat menjalan ajaran agama dalam kehidupan sekolah

1.2.2 Siswa dapat berpikir dan berprilaku ajaran agama dalam lingkungan sekolah

Hari/Tanggal $20 \ldots$

Tema Penilaian Diri : Ketaatan Beribadah Petunjuk: Berilah tanda centang $(\sqrt{ })$ pada kolom yang sesuai dengan keadaan kalian yang sebenarnya.

\begin{tabular}{|c|l|l|l|l|l|}
\hline No & Pernyataan & Selalu & Sering & $\begin{array}{l}\text { Kadang- } \\
\text { kadang }\end{array}$ & $\begin{array}{l}\text { Tidak } \\
\text { pernah }\end{array}$ \\
\hline 1 & $\begin{array}{l}\text { Selalu berdoa } \\
\text { sebelum } \\
\text { melakukan } \\
\text { aktivitas }\end{array}$ & & & & \\
\hline 2 & $\begin{array}{l}\text { Tidak } \\
\text { mengganggu } \\
\text { teman yang } \\
\text { beragama lain } \\
\text { ketika berdoa } \\
\text { sesuai } \\
\text { agamanya }\end{array}$ & & & & \\
\hline 3 & $\begin{array}{l}\text { Berani } \\
\text { mengakui } \\
\text { kesalahannya. }\end{array}$ & & & & \\
\hline 4 & $\begin{array}{l}\text { Aktif } \\
\text { mengikuti } \\
\text { kegiatan } \\
\text { keagamaan } \\
\text { yang }\end{array}$ & & & & \\
\hline
\end{tabular}

\begin{tabular}{|c|l|l|l|l|l|}
\hline & $\begin{array}{l}\text { dijadwalkan } \\
\text { guru }\end{array}$ & & & & \\
\hline 5 & $\begin{array}{l}\text { Mau } \\
\text { mengajak } \\
\text { teman } \\
\text { seagamanya } \\
\text { untuk } \\
\text { melakukan } \\
\text { ibadah } \\
\text { bersama }\end{array}$ & & & & \\
\hline 6 & $\begin{array}{l}\text { Melaksanakan } \\
\text { ibadah tepat } \\
\text { waktu }\end{array}$ & & & & \\
\hline 7 & $\begin{array}{l}\text { Mengingatkan } \\
\text { teman untuk } \\
\text { selaku berdoa }\end{array}$ & & & & \\
\hline 8 & $\begin{array}{l}\text { Berteman } \\
\text { tanpa } \\
\text { membedakan } \\
\text { agama }\end{array}$ & & & & \\
\hline 9 & $\begin{array}{l}\text { Tidak } \\
\text { mengejek } \\
\text { ajaran agama } \\
\text { lain }\end{array}$ & & & & \\
\hline 10 & $\begin{array}{l}\text { Berterima } \\
\text { kasih atas } \\
\text { pemberian } \\
\text { orang lain }\end{array}$ & & & & \\
\hline
\end{tabular}

Catatatan:

Untuk setiap item diberi skor sebagai berikut:

Selalu $\quad=4$

Sering $=3$

Kadang-kadang $=2$

Tidak Pernah $=1$

Rumus Penilaian:

Nilai $=\frac{\text { SkorPerolehan }}{\text { SkorMaksimal }} \times 100 \%$

Keterangan :

Nilai 91 - 100 berarti sangat baik (sudah membudaya).

Nilai 71 - 90 berarti baik (mulai berkembang)

Nilai 61 - 70 berarti cukup (mulai terlihat) 
Nilai kurang dari 60 berarti kurang (belum terlihat)

(Modifikasi Direktorat Pembinaan Sekolah

Dasar, 2016)

\section{3). Instrumen Evaluasi Diri}

Lembar Instrumen Evaluasi Diri

"Rasa Syukur dan Bangga Terhadap

Peninggalan Sejarah pada Masa Islam di

Indonesia sebagai Karunia Tuhan YME"

Nama Siswa

Kelas/Semester $\quad:$ IV/1

Tema/Subtema :

Indahnya Kebersamaan / Bersyukur atas

Keberagaman

Mata Pelajaran :

Ilmu Pengetahuan Sos

1.3 Menerima Karunia Tuhan Yang Maha

Esa yang telah menciptakan manusia

dan lingkungannya

Indikator

1.3.1 siswa dapat menampilkan rasa syukur terhadap nikmat peninggalan pada masa Islam di daerahnya

1.3.2 siswa dapat menampilkan rasa bangga terhadap peninggalan pada masa islam didaerahnya

Hari/Tanggal $\quad$ :..............20....

Tema Penilaian Diri : Mensyukuri Karunia

Tuhan YME

\section{Catatatan:}

1. Bila menjawab YA pada pernyataan positif, maka skornya 1 dan bila menjawab Tidak maka skornya 0

2. Bila menjawab Tidak pada pernyataan negatif, maka skornya 0 dan bila menjawab Ya maka skornya 1

3. Guru hendaknya memandu pemahaman peserta didik terhadap instrumen evaluasi diri, terutama dalam memahami pernyataan sehingga tidak terjadi salah tafsir.

\begin{tabular}{|c|c|c|c|}
\hline No & Pernyataan & $\mathrm{Ya}$ & Tidak \\
\hline 1 & $\begin{array}{l}\text { Saya tidak tertarik bila } \\
\text { berkunjung ke tempat } \\
\text { peninggalan- peninggalan } \\
\text { Islam }\end{array}$ & & \\
\hline 2 & $\begin{array}{l}\text { Saya kagum terhadap tokoh- } \\
\text { tokoh yang menyebarkan } \\
\text { Islam di Indonesia }\end{array}$ & & \\
\hline 3 & $\begin{array}{l}\text { Saya selalu merasa bersyukur } \\
\text { di lahirkan di lingkungan } \\
\text { keluarga beragama Islam }\end{array}$ & & \\
\hline 4 & $\begin{array}{l}\text { Saya malu apabila memakai } \\
\text { jilbab (pr) dan memakai baju } \\
\text { koko (lk) jika keluar rumah }\end{array}$ & & \\
\hline 5 & $\begin{array}{l}\text { Saya selalu rajin berjamaah } \\
\text { di mesjid }\end{array}$ & & \\
\hline 6 & $\begin{array}{l}\text { Saya senang bila melihat } \\
\text { tayangan di TV mengenai } \\
\text { peninggalan-peninggalan } \\
\text { pada zaman Islam di } \\
\text { Indonesia }\end{array}$ & & \\
\hline 7 & $\begin{array}{l}\text { Saya merasa senang bila } \\
\text { dapat turut serta dalam } \\
\text { melestarikan dan menjaga } \\
\text { peninggalan sejarah }\end{array}$ & & \\
\hline
\end{tabular}

*Berilah tanda centang $(\sqrt{ })$ pada kolom sesuai kriteria yang ditunjukkan siswa.

Rumus Penilaian:

$$
\text { Nilai }=\frac{\text { SkorPerolehan }}{\text { SkorMaksimal }} \times 100 \%
$$

Keterangan :

Nilai 91 - 100 berarti sangat baik (sudah membudaya).

Nilai $71-90$ berarti baik (mulai berkembang)

Nilai 61 - 70 berarti cukup (mulai terlihat) Nilai kurang dari 60 berarti kurang (belum terlihat) (Modifikasi Prastowo, 2013). 


\section{Simpulan}

Penilaian adalah suatu proses untuk mengetahui keberhasilan suatu program kegiatan yang sesuai dengan tujuan atau kriteria yang telah ditetapkan. Penilaian dapat dilakukan dengan tepat apabila tersedia data yang sesuai dan memadai. Guna memperoleh data diperlukan instrumen penilaian dari berbagai model yang sesuai dengan tujuan. Untuk mengetahui keberhasilan dalam pembelajaran penanaman nilai-nilai karakter diperlukan instrumen penilaian yangsesuai dengan tujuannya, dengan cara membandingkan perilaku anak dengan standar (indikator) karakter yang ditetapkan.

Dengan instrumen penilaian pendidikan karakter dalam pembelajaran di SD akan dapat memudahkan guru-guru SD dalam melaksanakan penilaian dalam pembelajaran dalam rangka pendidikan karakter dan pada gilirannya implementasi pendidikan karakter bagi peserta didik SD dapat berlangsung guna mendukung terwujudnya tujuan pendidikan nasional.

\section{Daftar Pustaka}

Direktorat Pembinaan Sekolah Dasar. (2016). Panduan Penilaian Untuk Sekolah Dasar. Jakarta: Kementrian Pendidikan dan Kebudayaan

Hidayatullah, F. (2009). Guru Sejati : Membangun Insan Berkarakter Kuat dan Cerdas. Surakarta: Yuma Pustaka.

Kesuma, Dharma., Triatna, Cepi., \& Permana, Johar. (2011). Pendidikan Karakter (Kajian Teori dan Praktik di Sekolah). Bandung: Rosdakarya.

Mulyasa. (2016). Manajeman Pendidikan Karakter. Jakarta: Bumi Aksara.

Prastowo, A. (2013). Menyusun Rencana Pelaksanaan Pembelajaran (RPP) Tematik Terpadu.

Samami, M. \& Hariyanto. (2011). Konsep dan Model Pendidikan Karakter. Bandung: Rosdakarya. 